\title{
The Lawyers Who Mistook a President FOR THEIR CLIENT
}

\author{
KATHLEEN CLARK ${ }^{*}$
}

I. INTRODUCTION. . . . . . . . . . . . . . . . . . . . 271

II. THE DEPARTMENT'S RECORD ON THE FOREIGN EMOLUMENTS CLAUSE. . . 273

A. Four Textual Elements in the Clause. . . . . . . . . . . . . . . . 273

B. Department of Justice Opinions Interpreting Those Four

Elements.................................. 275

1. "Office of Profit or Trust".......................... 275

2. "[A]ny present, Emolument, Office, or Title, of any kind

whatever".............................. 277

3. "[F] rom any King, Prince, or foreign State”... . . . . . . . . . 279

4. "[W]ithout the Consent of the Congress". ............. 283

III. TRUMP INTERPRETATION OF THE CLAUSE: PROTECT TRUMP, NOT THE

REPUBLIC............................... 285

A. Pre-Inauguration: Trump's Personal Lawyers Narrowly Construe Clause to Promote His Financial Interests.. . . . . . . . . . . . 285

B. Post-Inauguration: Department of Justice Adopts Trump's Narrow Interpretation............................ 287

IV. THE DEPARTMENT's REVERSAL: FROM ROBUST TO RISIBLE

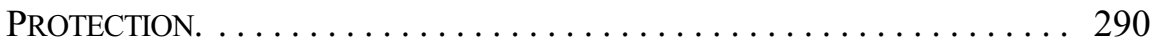

APPENDIX I: THE DEPARTMENT OF JUSTICE OPINIONS ON THE FOREIGN

EMOLUMENTS ClAUSE. . . . . . . . . . . . . . . . 292

APPENDIX II: COMPTROLLER GENERAL OPINIONS ON THE FOREIGN

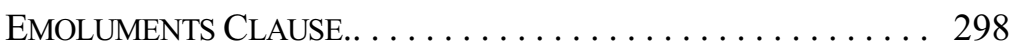

APPENDIX III: OTHER FEDERAL GOVERNMENT OPINIONS ON THE FOREIGN

EMOLUMENTS CLAUSE..................... 303

\section{INTRODUCTION}

The U.S. Department of Justice has a long history of interpreting the Constitution's Foreign Emoluments Clause (the "Clause") to protect the government against foreign influences. Over the course of a century and a half, the Department has issued more than fifty opinions interpreting the Clause to prohibit federal officials from accepting any benefit from foreign governments, even if the benefit is small in size, is part of an arms-length transaction, is funneled through an intermediary, or if the official's government responsibilities don't affect the foreign government. ${ }^{1}$ Consistent with both the language and purpose of the Clause, the Department has been vigilant in safeguarding our Republic from potentially corrupt foreign government influence by preventing foreign governments from currying favor with federal officials.

That strong and consistent record changed on June 9, 2017, when the Department responded to the first of three lawsuits (the "Emoluments Litigation"), all of which alleged that President Donald Trump violated the

* Professor of Law, Washington University.

1. See infra app. I. 
Foreign Emoluments Clause by accepting payments from foreign governments through his commercial establishments, including his Washington, D.C. hotel. ${ }^{2}$ In its memorandum of law and later pleadings, the Department veered away from its long track record of vigilance on behalf of the Republic. Instead, the Department adopted the legal arguments put forward by Donald Trump's personal lawyers, who were pushing for a narrow interpretation of the Clause in order to advance Trump's private financial interests. ${ }^{3}$ That narrow interpretation of the Clause would permit the President - and all federal officials - to accept unlimited amounts of money from foreign governments if the money comes through commercial transactions with an entity owned by the federal official. In the Emoluments Litigation, the Department has chosen to protect the personal financial interests of Donald Trump instead of the institutional interests of the United States. Department lawyers have mistaken this President for their actual client, the United States.

Other articles and commentaries about the Emoluments Litigation have focused on competing definitions of "emolument," but this is the first article to take a comprehensive look at the Clause as interpreted by the Department in more than fifty opinions over 150 years. The consistent historical record ${ }^{5}$ stands in sharp contrast to the position that the Department has taken in the Emoluments Litigation: Advocating for Donald Trump's personal enrichment. ${ }^{6}$

Part II of this article provides a textual analysis of the four distinct elements found in the Foreign Emoluments Clause - the federal offices covered, the types of benefits and foreign entities restricted, and the role of Congressional consent-and reviews how Department opinions have interpreted each of those four elements to protect the Republic against potentially malign foreign influences. Part III examines the arguments that Donald Trump's personal lawyers put forward prior to his inauguration, demonstrates how those arguments would dramatically narrow application of the Clause, and shows that the Department adopted those same arguments to defend President Trump when he was sued in the three Emoluments Litigation cases. Part IV analyzes the Department's decision to reverse its earlier position and compares this reversal with other examples of Department reversals. While some of the earlier reversals have been controversial, this is the first time a reversal has served the personal

2. Memorandum of Law in Support of Defendant's Motion to Dismiss at 4-5, Citizens for Responsibility \& Ethics in Wash. v. Trump, 276 F. Supp. 3d 174 (S.D.N.Y. 2017) (No. 1:17-cv00458-RA) [hereinafter CREW v. Trump, Memorandum of Law].

3. See id. at 26 (arguing that the Emoluments Clause was never intended to reach benefits arising from a President's private business pursuits).

4. See, e.g., Norman L. Eisen et al., The Emoluments Clause: Its Text, Meaning, And Application to Donald J. Trump 11-12 (2016); Andy Grewal, The Trump Hotel Isn't Unconstitutional, YALE J. on ReG.: NOTICE \& COMMENT (Nov. 22, 2016), http://yalejreg.com/nc/ the-trump-hotel-isnt-unconstitutional/ [https://perma.cc/EE5M-DQAK]; John Mikhail, A Note on the Original Meaning of "Emolument," BALKiniZATION (Jan. 18, 2017), https://balkin.blogspot. com/2017/01/a-note-on-original-meaning-of-emolument.html [https://perma.cc/23HG-A5T2].

5. See infra app. I.

6. See CREW v. Trump, Memorandum of Law, supra note 2. 
financial interest of a president rather than the political ideology of his party.

II. THE DEPARTMENT’S RECORD ON THE FOREIGN EMOLUMENTS ClAUSE

\section{A. Four Textual Elements in the Clause}

The Foreign Emoluments Clause of the Constitution states:

no Person holding any Office of Profit or Trust under [the United States], shall, without the Consent of the Congress, accept of any present, Emolument, Office, or Title, of any kind whatever, from any King, Prince, or foreign State.

The Clause was not part of the original proposed text of the Constitution, but it was added at the Constitutional Convention in order to "prevent corruption." "The Clause can be divided into its four component parts:

- " "no Person holding any Office of Profit or Trust under" the United States

- "without the Consent of the Congress"

- "shall ... accept of any present, Emolument, Office, or Title, of any kind whatever"

- "from any King, Prince, or foreign State."

To determine whether a particular arrangement would violate the Clause, we need to ask four distinct questions (changing their order slightly from above):

(1) Does the person involved hold "any Office of Profit or Trust under" 10 the United States?

(2) Does the benefit involved constitute "any present, Emolument, Office, or Title, of any kind whatever?"11

(3) Is that benefit "from any King, Prince, or foreign State?"12

If the answers to those three questions are all "yes," then ask:

(4) Has Congress consented to this arrangement?

Up until 2017, there had been little occasion for courts to interpret the Clause. A search of the WESTLAW database on November 15, 2016 identified only two

7. U.S. Const. art. I, $\S 9$, cl. 8. The Foreign Emoluments Clause is part of a longer sentence, which reads in full:

No Title of Nobility shall be granted by the United States: And no Person holding any

Office of Profit or Trust under them, shall, without the Consent of the Congress, accept

of any present, Emolument, Office, or Title, of any kind whatever, from any King,

Prince, or foreign State.

In the text of this article, I have deleted the words before the colon and substituted the phrase, "the United States" in place of "them."

8. Zephyr Teachout, Gifts, Offices, and Corruption, 107 Nw. U. L. REv. 30, 34 (2012) (quoting Governor Edmund Randolph during the debate about the Constitution in Virginia).

9. U.S. CONST. art. I, $\S 9$, cl. 8 .

10. Id.

11. Id.

12. Id. 
court cases interpreting the Clause: a 2006 appellate decision rejecting a soldier's claim that his participation in a United Nations Peacekeeping Force would violate the Clause, ${ }^{13}$ and a 1982 Court of Claims decision awarding a retired member of the Coast Guard retirement benefits that had been withheld as a consequence of his being employed by the government of Tasmania. ${ }^{14}$

This limited case law does not mean there is a paucity of law on the subject. Congress has periodically enacted legislation pursuant to the Clause, granting its consent to federal officials accepting benefits from foreign governments that the Clause would otherwise prohibit. ${ }^{15}$ From 1789 until 1966, Congress handled its consent function on an ad hoc basis. ${ }^{16}$ Federal officials who wanted to accept a "present, Emolument, Office, or Title" from a foreign government would seek specific Congressional consent. ${ }^{17}$ In response, Congress sometimes enacted private legislation granting its consent for that specific benefit. On August 30, 1856, for example, Congress passed a resolution permitting the Superintendent of the Coast Survey to accept a gold medal from the King of Sweden. ${ }^{18}$ Starting in 1966, Congress has provided its consent in a more systematic way, enacting legislation allowing federal officials to accept a "present, Emolument, Office, or Title" from a foreign government under limited circumstances. ${ }^{19}$ Federal employees may now accept gifts of modest size from foreign governments and combat-related decorations from foreign governments if the employee's

13. United States ex rel. New v. Rumsfeld, 448 F.3d 403, 410 (D.C. Cir. 2006).

14. Ward v. United States, 1 Cl. Ct. 46 (1982). The Comptroller General ruled that the government must withhold from a retiree's retirement pay the amount he received from the Tasmanian government. Id. at 48 (To C. C. Gordon, United States Coast Guard, 44 Comp. Gen. 130, 131 (1964) [hereinafter To C. C. Gordon], aff'd by To Mr. Harvey E. Ward, USCG, Retired, B-154213 Comp. Gen. (1964), but Congress eventually passed a private bill awarding the retiree \$15,475.59. Priv. L. No. 98-14, 98 Stat. 3420 (1984).

The Westlaw search did identify a third court decision interpreting Article I, Section 9, Clause 8 of the Constitution-Eskra v. Morton, 524 F.2d 9 ( $7^{\text {th }}$ Cir. 1975) - but that case dealt with the constitutional prohibition on granting a title of nobility, based on the words that precede the colon in Article I, Section 9, Clause 8.

15. See, e.g., Priv. L. No. 98-14, 98 Stat. 3420 (1984).

16. In 1881, Congress set up a specific procedure for obtaining Congressional consent in the future. Act of Jan. 31, 1881, ch. $32 \S 3,21$ Stat. 603 (1881). It required "any present, decoration, or other thing . . c conferred or presented by any foreign government to any officer of the United States," to "be tendered through the Department of State," which was not to deliver it to the officer "unless so authorized by act Congress." Id.; see Memorandum from Ellis Lyons, Assistant Att'y Gen., Office of Legal Counsel, The Constitutional Prohibition Against Acceptance of Gifts from Foreign Potentates (Sept. 23, 1952) [hereinafter Lyons Memorandum] (describing how the executive branch implemented the Act of Jan. 31, 1881).

17. U.S. Const. art. I, § 9, cl. 8; Act of Jan. 31, 1881, ch. $32 \S 3,21$ Stat. 603 (1881).

18. Pub. Res. 4, 34th Cong., 11 Stat. 152 (1856).

19. Act of Sept. 6, 1966, Pub. L. No. 89-554, § 7341, 80 Stat. 378, 526-27 (referring to the phrase "present, Emolument, Office, or Title," as defined in the Constitution as "[a] present, decoration, or other thing presented or conferred"); see also U.S. Const. art. I, § 9, cl. 8. 
employing agency provides its approval. ${ }^{20}$ Similarly, a retired member of the military - who is deemed to hold an "Office of Profit or Trust" even after retirement ${ }^{21}$ - may accept a military office in, and compensation from, a newly democratic country if executive branch officials approve. ${ }^{22}$

In addition to these Congressional enactments, there is a substantial body of law interpreting the Clause in the form of Department of Justice opinions, letters, and memoranda dating back to $1854 .{ }^{23}$ The following section examines how the Department has interpreted the four components of the Clause.

\section{B. Department of Justice Opinions Interpreting Those Four Elements}

The Department has repeatedly been called upon to interpret the Clause and determine whether it prohibits the acceptance of benefits from foreign governments. ${ }^{24}$ While the Department's position on certain issues has varied over time, it has consistently interpreted the Clause broadly to protect the Republic against foreign government influences. ${ }^{25}$

1. "Office of Profit or Trust".--The first element of the Clause requires inquiry into whether an individual who seeks to accept a benefit holds an "Office of Profit or Trust" under the United States. ${ }^{26}$ The Department has determined that the Clause applies to the President, ${ }^{27}$ "constitutional officers . . . [as well as] government employees, 'lesser functionaries' who are subordinate to officers." ${ }^{28}$

20. 5 U.S.C. $\S 7342(c)-(d)(2019)$.

21. Applicability of 18 U.S.C. $\S 219$ to Retired Foreign Serv. Officers, 11 Op. O.L.C. 67,68 (1987) (referring to judicial "and administrative rulings dealing with the status of retired military officers as 'officers of the United States"'). Numerous Comptroller General opinions assert that retired members of the military are subject to the clause. See, e.g., To C. C. Gordon, supra note 14, at 130 (retired members of the armed forces hold "an office of profit and trust under the Federal Government after retirement" because they "remain a part of the service and are subject to recall to active duty in time of war or national emergency").

22. 10 U.S.C. $\S 1060$ (c) (2019).

23. See infra app. I. In addition, the Comptroller General has published 30 opinions on the clause, see app. II, and three other federal offices have opined on the clause. See app. III.

24. See, e.g., Applicability of the Emoluments Clause \& the Foreign Gifts \& Decorations Act to the President's Receipt of the Nobel Peace Prize, 33 Op. O.L.C. 1 (2009); Emoluments Clause \& World Bank, 25 Op. O.L.C. 113, 114 (2001); Proposal that the President Accept Honorary Irish Citizenship, 1 Op. O.L.C. Supp. 278 (1963).

25. See, e.g., Applicability of the Emoluments Clause \& the Foreign Gifts \& Decorations Act to the President's Receipt of the Nobel Peace Prize, 33 Op. O.L.C. 1 (2009); Emoluments Clause \& World Bank, 25 Op. O.L.C. 113, 114 (2001); Proposal that the President Accept Honorary Irish Citizenship, 1 Op. O.L.C. Supp. 278 (1963).

26. See generally U.S. Const. art. I, § 9, cl. 8.

27. Applicability of the Emoluments Clause \& the Foreign Gifts \& Decorations Act to the President's Receipt of the Nobel Peace Prize, 33 Op. O.L.C. 1, 13 (2009); see also Proposal that the President Accept Honorary Irish Citizenship, 1 Op. O.L.C. Supp. 278 (1963).

28. Emoluments Clause \& World Bank, 25 Op. O.L.C. 113, 114 (2001). 
It also applies to retired members of the military, ${ }^{29}$ but not to retired members of the foreign service. ${ }^{30}$

The Department's position on the reach of the Clause - in other words, which federal offices count as an "Office of Profit or Trust" - has varied over time. ${ }^{31}$ A 1974 opinion said "there is a substantial question whether membership on the [National Voluntary Service Advisory] Council constitutes holding an office of profit or trust under the United States," "32 because the "primary responsibilities of the Council are to advise" on policy, "make recommendations," and "submit an annual report containing its recommendations." ${ }^{" 33}$ On the other hand, a 1991 opinion declared that federal advisory committee members "hold offices of profit or trust within the meaning of the Emoluments Clause," ${ }^{34}$ and a 1993 opinion found that nongovernment members of the Administrative Conference of the United States (ACUS) hold an Office of Trust and are therefore "brought within the Clause," even though they are unpaid and therefore do not hold an "Office of Profit." 35

But the following year, the Department again reversed course, indicating that "not every member of an advisory committee necessarily occupies an 'Office of Profit or Trust' under the Clause" and that the "1991 [Office of Legal Counsel] opinion on advisory committees was overbroad." ${ }^{36}$ The OLC confirmed that reversal in a 1996 opinion "reject[ing] the sweeping and unqualified view, expressed on one occasion by our Office, that federal advisory committee members, as such, are subject to the Emoluments Clause," ${ }^{, 37}$ and a 2010 ruling

29. Applicability of the Emoluments Clause \& the Foreign Gifts \& Decorations Act to the President's Receipt Nobel Peace Prize, 33 Op. O.L.C. 1, 4 n.2 (2009) (citing Memorandum to File from Richard L. Shiffrin, Deputy Assistant Att'y Gen., Office of Legal Counsel (Aug. 27, 1996) [hereinafter Shiffrin Memorandum] (retired military officers continue to "hold[] [an] Office of Profit or Trust" under the United States and hence remain subject to the Emoluments Clause)).

30. Application of the Emoluments Clause to a Member of the FBI Director's Advisory Board, 31 Op. O.L.C. 154, 155 (2007).

31. See, e.g., Memorandum from Robert G. Dixon, Jr., Assistant Att'y Gen., Office of Legal Counsel, to Dudley H. Chapman, Associate Counsel to the President, Appointment of a Foreign National to the National Voluntary Service Advisory Council, (May 10, 1974) [hereinafter Dixon Memorandum]; Applicability of the Emoluments Clause to Non-Gov't Members of ACUS, 17 Op. O.L.C. 114, 123 (1993); Applicability of 18 U.S.C. $§ 219$ to Members of Fed. Advisory Comms., 15 Op. O.L.C. 65,68 (1991).

32. Dixon Memorandum, supra note 31.

33. Id. at 5 .

34. Applicability of 18 U.S.C. $\S 219$ to Members of Fed. Advisory Comms., 15 Op. O.L.C. 65, 68 (1991).

35. Applicability of the Emoluments Clause to Non-Gov't Members of ACUS, 17 Op. O.L.C. 114, 123 (1993).

36. Letter from Walter Dellinger, Assistant Att'y Gen., Office of Legal Counsel, to Conrad K. Harper, Legal Advisor, U.S. Dep't State (Mar. 1, 1994) [hereinafter Dellinger Letter] (reprinted in Gary J. Edles, Service on Federal Advisory Committees: A Case Study of OLC's Little-Known Emoluments Clause Jurisprudence, 58 ADMIN. L. REV. 1, 36 (2006)).

37. Advisory Comm. on Int'l Econ. Policy, 20 Op. O.L.C. 123, 123 (1996) (citing 
that nongovernment members of ACUS are not subject to the Emoluments Clause because they do not hold "Office[s] of Profit or Trust." 38

The Department's current position is that "in order to qualify as an 'Office of Profit or Trust," a position must "involve some exercise of governmental authority." ${ }^{39}$ Positions that are purely advisory in nature, such as membership on many federal advisory committees, do not involve the exercise of sovereign authority and therefore are not subject to the Clause. ${ }^{40}$

2. "[A]ny present, Emolument, Office, or Title, of any kind whatever".--The second issue is whether a particular benefit constitutes a "present, Emolument, Office, or Title" restricted by the Clause. In several opinions, the Department notes that a particular benefit may be characterized as either a present or an emolument, with no need to differentiate between the two. ${ }^{41}$ The Department has

Applicability of 18 U.S.C. $\S 219$ to Members of Fed. Advisory Comms., 15 Op. O.L.C. 65, 68 (1991)).

38. Applicability of the Emoluments Clause to Non-Gov't Members of ACUS, 34 Op. O.L.C. 1, 1 (2010); see also Application of the Emoluments Clause to a Member of the FBI Dir.'s Advisory Bd., 31 Op. O.L.C. 154, 154 (2007) (a member of the FBI Director's Advisory Board does not hold an "Office of Profit or Trust"); Application of the Emoluments Clause to a Member of the President's Council on Bioethics, 29 Op. O.L.C. 55, 56 (2005) ("a purely advisory position is not an 'Office under the United States' and, hence, not an 'Office of Profit or Trust'"); Applicability of 18 U.S.C. $§ 219$ to Representative Members of Fed. Advisory Comms., 23 Op. O.L.C. 213, 213 (1999) (explicitly superseding the 1991 opinion); Application of the Emoluments Clause to "Representative" Members of Advisory Comms., 21 Op. O.L.C. 176, 177 (1997) (declaring that representative members of advisory committees "do not, in our view, hold offices of profit or trust under the United States" and therefore "are not covered by the Clause"). For a thorough discussion of OLC's change on this issue, see Edles, supra note 36, at 1.

39. Application of the Emoluments Clause to a Member of the President's Council on Bioethics, 29 Op. O.L.C. 55, 56, 64 (2005).

40. Id. at 64 .

41. See, e.g., Applicability of the Emoluments Clause \& the Foreign Gifts \& Decorations Act to the President's Receipt of the Nobel Peace Prize, 33 Op. O.L.C. 1, 4-5 (2009) ("the [Nobel] Peace Prize, including its [\$1.4 million] monetary award, is a 'present' or 'Emolument . . . of any kind whatever,' $\ldots$ the medal and the diploma . . . constitute a 'present' or 'Emolument . . . of any kind whatever' within the meaning of the Emoluments Clause"); Letter from William H. Rehnquist, Assistant Att'y Gen., Office of Legal Counsel, to Joseph F. Hennessey, Gen. Couns., Atomic Energy Comm'n, (Sept. 29, 1969) [hereinafter Rehnquist Letter] (“the difference might be looked on as a 'present' or 'Emolument' within Article I, section 9, clause 8 of the Constitution"); Memorandum from Norbert A. Schlei, Assistant Att'y Gen., Office of Legal Counsel, to Andrew F. Gehmann, Executive Assistant, Office Att'y Gen., Invitation by Italian Government to Officials of the Immigration \& Naturalization Service \& a Member of the White House Staff \& Their Wives, to be Guests of the Italian Government, All Expenses, Including Travel, to be Borne by that Government (Oct. 16, 1962) [hereinafter Schlei Memorandum] (a proposed trip to Italy for an employee and his spouse "can be regarded as being literally a 'present' and possibly as an 'Emolument'”); Memorandum from Leon Ulman, Deputy Assistant Att'y Gen., Office of Legal Counsel, to John G. Gaine, Gen. Counsel, Commodity Futures Trading Comm'n, Expense 
found a wide range of benefits to be an emolument or gift, including a salary and pension benefits from a foreign government, ${ }^{42}$ compensation for services performed, ${ }^{43}$ "lodging, meals, and transportation," ${ }^{44}$ an opportunity "to conduct research of [the employee's] choice for an extended period of time at research institutions in" a foreign country, ${ }^{45}$ and awards that include cash prizes. ${ }^{46}$

Reimbursement in Connection with Chairman Stone's Trip to Indonesia (Aug. 11, 1980) [hereinafter Ulman Memorandum to Gaine] ("Ordinarily, reimbursement from a foreign government of a public official's travel expenses would be considered a 'present' or 'emolument"'); Applicability of the Emoluments Clause \& the Foreign Gifts \& Decorations Act to the President's Receipt of the Nobel Peace Prize, 33 Op. O.L.C. 1, 4-5 (2009) ("the [Nobel] Peace Prize, including its [\$1.4 million] monetary award, is a 'present' or 'Emolument . . of any kind whatever,' $\ldots$ the medal and the diploma . . . constitute a 'present' or 'Emolument . . . of any kind whatever' within the meaning of the Emoluments Clause"); see also Applicability of the Emoluments Clause \& the Foreign Gifts \& Decorations Act to the Göteborg Award for Sustainable Dev., 34 Op. O.L.C. 1, 2 (2010) (noting that there was no need to determine "whether each element of the Göteborg Award - the cash prize, the travel to Sweden, or the ceremonial globe-is a 'present' or 'Emolument . . . of any kind whatever,'" because the Award did not come from a "foreign State").

The distinction between a "present" and an "emolument" can be important where Congress has consented to the acceptance of certain "presents," but has not consented to other benefits. See Application of the Emoluments Clause of the Constitution \& the Foreign Gifts \& Decorations Act, 6 Op. O.L.C. 156 (1982) (noting that in the Foreign Gift and Decorations Act, 5 U.S.C. $§ 7342$, Congress consented to federal employees' accepting modest gifts from foreign governments, but did not consent to employees' receipt of compensation for services).

42. Constitutionality of Cooperative Int'l Law Enf't Activities Under the Emoluments Clause, 20 Op. O.L.C. 346 (1996) (employment by the navy of the United Kingdom); Applicability of Emoluments Clause to Emp't of Gov't Emps. by Foreign Pub. Univs., 18 Op. O.L.C. 13 (1994) (employment by a foreign public university); Applicability of the Emoluments Clause to Non-Gov't Members of ACUS, 17 Op. O.L.C. 114 (1993) (same); Authority of Foreign Law Enf't Agents to Carry Weapons in the United States, 12 Op. O.L.C. 67 (1988).

43. Emoluments Clause \& World Bank, 25 Op. O.L.C. 113, 114 (2001) ("We have . . long found that contractual relationships [to perform special projects] give rise to 'Emoluments' within the meaning of the Emoluments Clause."); Applicability of the Emoluments Clause to Non-Gov't Members of ACUS, 17 Op. O.L.C. 114 (1993) (remuneration for academic work or research or teaching); Authority of Foreign Law Enf't Agents to Carry Weapons in the United States, 12 Op. O.L.C. 67 (1988).

44. Assumption by China of Expenses of U.S. Delegation - Constitution (Art. I, § 9, cl. 8), 2 Op. O.L.C. 345, 345 (1977); see also Application of the Emoluments Clause to a Member of the FBI Dir.'s Advisory Bd., 31 Op. O.L.C. 154 n.2 (2007) (Ordinarily, reimbursement from a foreign government of a public official's travel expenses would be considered a "present" or “emolument."); Memorandum from J. Lee Rankin, Assistant Att'y Gen., Office of Legal Counsel, to Att'y Gen., Membership of Judge Parker on the International Law Commission (Nov. 27, 1953) [hereinafter Rankin Memorandum] ("reimbursement for ... travel expenses and the additional costs of living away from home"); Schlei Memorandum, supra note 41 (travel to Italy for the employee and his spouse).

45. Letter from Robert B. Shanks, Deputy Assistant Att'y Gen., Office of Legal Counsel, to 
Particularly noteworthy is a 1993 opinion concluding that the Clause reaches a law firm's "distribution from their partnerships that includes some proportionate share of the revenues generated from the partnership's foreign government clients. ${ }^{\prime 47}$ The Clause prohibits a government official from accepting funds derived from a foreign government's payment to a firm partially owned by that official. $^{48}$

Among the dozens of published Department of Justice opinions addressing emoluments, only three identify benefits that should not be categorized as "emoluments." A 1954 opinion found that "the Constitutional provision would not prevent an officer of the United States from receiving damages arising from some wrongful act of a foreign state," but then went on to find that the benefit at issue, an "annuity payment of $\$ 263$ a month for life to Mr. Newkirk is not exclusively a payment for damages," and was prohibited because it was "intended to restore Mr. Newkirk to the financial position he would have enjoyed had he continued as a judge in the German Government until retirement. ${ }^{{ }^{49}}$ A 1969 opinion found that money received by Atomic Energy Commission employees from the government of India did not constitute an "added benefit for the employee[s]" because the arrangement was "no more than a bookkeeping device for the sake of the mutual convenience of the United States and the Indian Government." ${ }^{50}$ A 1981 opinion addressing both the Foreign and Domestic Emoluments Clauses found that President Reagan's vested retirement benefits from his prior service as California governor were "not emoluments in the constitutional sense," noting that their "receipt does not violate the spirit of the Constitution because they do not subject the President to any improper influence." ${ }^{51}$

3. "[F] rom any King, Prince, or foreign State".--The third question to ask is whether the benefit is "from any King, Prince, or foreign State."

Walter T. Skallerup, Jr., Gen. Couns., Dep't Navy, (Mar. 17, 1983) [hereinafter Shanks Letter].

46. See, e.g., id. ( $\$ 24,000$ award for a "Senior U.S. Scientist"); Applicability of the Emoluments Clause \& the Foreign Gifts \& Decorations Act to the Göteborg Award for Sustainable Dev., 34 Op. O.L.C. 1 (2010) (\$71,000 cash prize, travel to Sweden, and a ceremonial globe); Applicability of the Emoluments Clause \& the Foreign Gifts \& Decorations Act to the President's Receipt of the Nobel Peace Prize, 33 Op. O.L.C. 1 (2009) (Nobel Peace Prize, including \$1.4 million, a certificate, and a gold medal).

47. Applicability of the Emoluments Clause to Non-Gov't Members of ACUS, 17 Op. O.L.C. 114, 114 (1993).

48. $I d$.

49. Memorandum from J. Lee Rankin, Assistant Att'y Gen., Office of Legal Counsel, to S.A. Andretta, Admin. Assistant Att'y Gen., Payment of Compensation to Individual in Receipt of Compensation from a Foreign Gov't 8 (Oct. 4, 1954) [hereinafter Rankin to Andretta Memorandum].

50. Rehnquist Letter, supra note 41 (emphasis added).

51. President Reagan's Ability to Receive Ret. Benefits from the State of Cal., 5 Op. O.L.C. 187, 192 (1981).

52. U.S. CONST. art. I, $\S 9$, cl. 8. 
comes directly from a "King, Prince, or foreign State," ${ }^{53}$ or from a commercial enterprise that is owned or controlled by a foreign government, then the answer is clearly "yes." ${ }^{14}$ But many Department of Justice opinions address situations that are more complicated: Where a benefit comes through an intermediary (such as a contractor or a foundation) with a connection to a foreign government, or even from a foreign public university.

On several occasions, federal employees wanted to receive compensation or travel expenses from an American organization in connection with that organization's contract with a foreign government. ${ }^{55}$ The "interposition" of an American intermediary between a foreign government and a federal employee does not automatically relieve the "employee of the obligations imposed by the Emoluments Clause." ${ }^{56}$ Instead, the key issue is whether the employee was selected by the American intermediary or by the foreign government. ${ }^{57}$ Where the foreign government made the selection, the Clause applies and the employee must not accept the benefit. ${ }^{58}$ On the other hand, where a foreign government contracted for an American university to select experts to provide consulting services, a federal employee could serve as a consultant and accept travel expenses because that emolument "cannot be said to be 'from' a foreign government within the meaning of" the Clause, even though the expenses were

53. See, e.g., Proposal that the President Accept Honorary Irish Citizenship, 1 Op. O.L.C. Supp. 278 (1963) (honorary Irish citizenship from the government of Ireland); Assumption by People's Republic of China of Expenses of U.S. Delegation, 2 Op. O.L.C. 345 (1978) (travel given by the People's Republic of China); Gifts from Foreign Prince, 24 Op. Att'y Gen. 116, 117 (1902) (quoting U.S. Const. art. I, § 9, cl. 9) (involving photographs given by Prince Henry of Prussia); Lyons Memorandum, supra note 16 (presents that Prince Abdullah Al-Faizal Ab Saud of Saudi Arabia, Minister of Interior and Public Health, gave to federal employees during his visit); Schlei Memorandum, supra note 41 (a trip to Italy given by the Italian government).

The Department has determined that international bodies in which the United States is a member are not "foreign states" under the Emoluments Clause. See, e.g., Emoluments Clause \& World Bank, 25 Op. O.L.C. 113, 113, 115 (2001) (noting "the role played by the United States in the World Bank as approved by Congress" and concluding that "an international organization such as the World Bank in which the United States participates" is not a "foreign State" under the clause); Rankin Memorandum, supra note 44 ("there is little or no basis for regarding service on an United Nations commission, even in an individual capacity, as coming within the purpose of the Constitutional provision").

54. Applicability of the Emoluments Clause to Non-Gov't Members of ACUS, 17 Op. O.L.C. 114, 121 (1993) ("There is no express or implied exception for emoluments received from foreign States when the latter act in some capacity other than the performance of their political or diplomatic functions").

55. See infra tbl. 1.

56. Application of the Emoluments Clause of the Constitution \& the Foreign Gifts \& Decorations Act, 6 Op. O.L.C. 156, 159 (1982).

57. Id. at 158 .

58. Id.; Application of Foreign Emoluments Clause to Part-Time Consultant for the Nuclear Regulatory Comm'n, 10 Op. O.L.C. 96 (1986). 
ultimately paid by that foreign government. ${ }^{59}$ Since the university had "complete discretion in the selection" of consultants, and the foreign government had "never sought to influence" the university's selection of consultants, the federal official could accept the benefit. ${ }^{60}$

Table 1: Federal Employee Working for Foreign Government Through US Organization

\begin{tabular}{|c|c|c|c|}
\hline Opinion & Nation & $\begin{array}{c}\text { Did foreign nation } \\
\text { select federal } \\
\text { employee? }\end{array}$ & $\begin{array}{c}\text { Was } \\
\text { emolument } \\
\text { from foreign } \\
\text { state? }\end{array}$ \\
\hline $\begin{array}{c}\text { Expense Reimbursement in } \\
\text { Connection with Chairman } \\
\text { Stone's Trip to Indonesia } \\
\text { (1980) }\end{array}$ & Indonesia & No $^{61}$ & No $^{62}$ \\
\hline $\begin{array}{c}\text { Application of the } \\
\text { Emoluments Clause of the } \\
\text { Constitution and the } \\
\text { Foreign Gifts and } \\
\text { Decorations Act (1982) }\end{array}$ & Mexico & $\mathrm{Yes}^{63}$ & $\mathrm{Yes}^{64}$ \\
\hline $\begin{array}{c}\text { Application of Foreign } \\
\text { Emoluments Clause to } \\
\text { Part-Time Consultant for } \\
\text { the Nuclear Regulatory } \\
\text { Commission (1986) }\end{array}$ & Taiwan & & \\
\hline
\end{tabular}

Several opinions have addressed whether a federal employee may accept compensation from a foreign public university. In a 1986 opinion permitting a federal government scientist to accept a $\$ 150$ stipend for reviewing a thesis from

59. Ulman Memorandum to Gaine, supra note 41 (emphasis added).

60. Id. at 3-4.

61. Id. at 4 (noting that the "contract gives [the foreign government] no veto power over" the university's choice).

62. Id. at 5 .

63. Application of the Emoluments Clause of the Constitution \& the Foreign Gifts \& Decorations Act, 6 Op. O.L.C. 158 (1982) (noting that "retention of the NRC employee by the consulting firm appears to be the principal reason for selection of the consulting firm by the Mexican government" and that "selection of personnel, remains with the Mexican government.").

64. Id.

65. Application of Emoluments Clause to Part-Time Consultant for the Nuclear Regulatory Comm'n, 10 Op. O.L.C. 96 (1986) (noting that "the Taiwanese government must approve Mr. A's participation on this contract").

66. Id. at 97 (the "proposed employment with a domestic corporation on a contact [sic] with a foreign government is within the proscription of the Emoluments Clause"). 
a public university in Australia, the Department noted that the university had "independence from the government," but did not come to any conclusion about whether the university should be considered a "foreign state" under the Clause. ${ }^{67}$ Instead, the opinion examined the facts "in light of the Framers' concerns expressed in the Emoluments Clause," and found that the situation did not "present[] the opportunity for 'corruption and foreign influence' that concerned the Framers and that we must presume exists whenever a gift or emolument comes directly from a foreign government." ${ }^{98}$ This gestalt approach in the 1986 opinion was later replaced in 1994 by a presumption that foreign public universities are "foreign states within the meaning of the [Emoluments] Clause," while allowing that presumption to be rebutted by evidence that the university acts independently of the government. ${ }^{70}$ That 1994 opinion found "compelling evidence" that faculty employment decisions at the University of Victoria were independent of the provincial government, and therefore the university would "not be considered to be a foreign state under the Emoluments Clause," allowing two NASA scientists to join its faculty and receive compensation from the university. ${ }^{71}$

67. Memorandum from Samuel A. Alito, Jr., Deputy Assistant Att'y Gen., Office of Legal Counsel, to H. Gerald Staub, Office of Chief Couns., NASA, Emoluments Clause Questions raised by NASA Scientist's Proposed Consulting Arrangement with the Univ. of New S. Wales 4 (May 23, 1986) [hereinafter Alito Memorandum] ("it is not so clear that [the university] should necessarily be regarded as a 'foreign state' for Emoluments Clause purposes, given its functional and operational separation and independence from the government").

68. Id . at 5. Those facts included the fact that invitation came from the chair of an academic department, and was extended "because of [the scientist's] international reputation as a scholar . . and not because of his position with the U.S. government;" the fee was "an amount ordinarily paid by departments to outside experts for services of this kind;" and the consultancy was "limited both in time and in substantive scope," and would not involve "any continuing relationship" with the university. $I d$.

69. Applicability of the Emoluments Clause to Emp't of Gov't Emps. by Foreign Pub. Univs., 18 Op. O.L.C. 13, 17 (1994); see also Applicability of the Emoluments Clause to NonGov't Members of ACUS, 17 Op. O.L.C. 114, 123 (1993) ("foreign governmental entities, including public universities, can and presumptively do constitute instrumentalities of foreign States under the Emoluments Clause"). Two opinions issued in 1990 and 1992 apparently found a foreign public institution of higher education to be a foreign state but may not have included the presumption analysis. Applicability of the Emoluments Clause to Emp't of Gov't Emps. by Foreign Pub. Univs., 18 Op. O.L.C. 13, 17 (1994) (citing Memorandum from Barbara E Armacost, Att'yAdvisor, Office of Legal Counsel, to Files, Emoluments Clause and Appointment to the President's Committee on the Arts and Humanities (Nov. 15, 1990) [hereinafter Armacost Memorandum]; and Memorandum Robert J. Delahunty, Acting Special Counsel, to File, Applicability of Emoluments Clause to Employment of CFTC Attorney by East China Institute of Politics \& Law (Aug. 27, 1992) [hereinafter Delahunty Memorandum]).

70. Applicability of the Emoluments Clause to Non-Gov't Members of ACUS, 17 Op. O.L.C. 120-22 (1993).

71. Applicability of the Emoluments Clause to Emp't of Gov't Emps. by Foreign Pub. Univs., 18 Op. O.L.C. 22 (1994). 
Where the benefit is provided by an organization that has ties to but is not formally part of a foreign government, the Department's analysis focuses on three issues: (1) whether the foreign government directed the benefit to the federal employee; (2) whether the foreign government controls the intermediary (by selecting its board members, for example); and (3) whether the foreign government provides substantial funding for the intermediary. ${ }^{72}$ Applying these criteria, the Department found that President Barack Obama could accept the 2009 Nobel Peace Prize even though he had been selected by a committee whose members were elected by the Norwegian Parliament. ${ }^{73}$ The Department determined that the Norwegian government had "no authority to compel the Committee to choose the Prize recipient; nor does it have any veto authority" over their selection, and the prize itself and the salaries of the committee members were funded by the private Nobel Foundation. ${ }^{74}$

As these opinions make clear, determining whether a benefit should be deemed to come from a foreign government is complicated because of the many factual and institutional variations in which these issues arise. But no matter what the variation, the Department focuses on whether a foreign government directed a benefit to a federal official.

4. "[W]ithout the Consent of the Congress".--The fourth question under the

72. Applicability of the Emoluments Clause \& the Foreign Gifts \& Decorations Act to the Göteborg Award for Sustainable Dev., 34 Op. O.L.C. 3 (2010); Applicability of the Emoluments Clause \& the Foreign Gifts \& Decorations Act to the President's Receipt of the Nobel Peace Prize, 33 Op. O.L.C. 8 (2009); see also Jeffrey Green, Application of the Emoluments Clause to Dep't of Defense Civilian Employees and Military Personnel, ARMY LAW., June 2013, at 15. Compare Shanks Letter, supra note 45 (foundation should be considered a foreign government because the German government established and administers it, provides most of its funding, created the program for honoring American scientists, and government officials are on the committee that selects awardees) with Memorandum from Daniel L. Koffsky, to File, Applicability of the Emoluments Clause to a U.S. Government Employee Who Performs Services for the Prince Mahidol Foundation (Nov. 19, 2002) [hereinafter Koffsky Memorandum] (cited in Applicability of the Emoluments Clause \& the Foreign Gifts \& Decorations Act to the President's Receipt of the Nobel Peace Prize, 33 Op. O.L.C. 11 (2009)) (foundation not a foreign government despite presence of Thai government and royalty because decision-making process evidenced "independent judgment" and most of its funding did not come from Thai government).

73. Applicability of the Emoluments Clause and the Foreign Gifts and Decorations Act to the President's Receipt of the Nobel Peace Prize, 33 Op. O.L.C. 13 (2009).

74. Id. at 9. The following year, the Department found that the decision to give a NOAA scientist the Göteborg Award for Sustainable Development "should not be deemed an action of a foreign state for the purposes of the Emoluments Clause" even though the jurors who made the decision were appointed by a board "consist[ing] of three officials of the City of Göteborg and one businessman," and the award was "funded one-third by the City and two-thirds by the private businesses" because "the jury de facto has the complete control of and the full responsibility for the selection process as well as the final decision." Applicability of the Emoluments Clause \& the Foreign Gifts \& Decorations Act to the Göteborg Award for Sustainable Dev., 34 Op. O.L.C. 3-5 (2010). 
Clause is whether Congress has given its consent for the employee to accept the benefit. Congressional consent requires an affirmative enactment of law rather than mere Congressional silence or acquiescence, ${ }^{75}$ and some of these enactments have explicitly acknowledged that they constitute consent under the Foreign Emoluments Clause. ${ }^{76}$ But an enactment can function as consent even if it does not use the term "consent" or specify a particular benefit as permitted under the Clause. ${ }^{77}$ For example, a Navy scientist was permitted to accept a $\$ 24,000$ award from a German government foundation because the award was similar to a scholarship, and Congress had consented to gifts "in the nature of an educational scholarship." ${ }^{78}$ Similarly, meteorologists from the U.S. Weather Service could accept compensation from the government of Ireland for serving in its Meteorological Service because the program for detailing U.S. meteorologists to Ireland had been "duly authorized by an act of . . Congress." " In other words, the enactment must signal that Congress has contemplated that a foreign government will provide the benefit at issue. ${ }^{80}$

Over the course of a century and a half, the Department has provided the Republic with robust protection from foreign governments' potentially corrupt influence by interpreting the Clause with the framers' purpose in mind. When the Department has been called upon to determine how the Clause applies, it has looked to the purpose of the Clause to inform its analysis. To determine whether the Clause applies to an advisory board member who serves on a part-time basis, the Department asked whether:

it would be reasonable to impart to the Framers an intent to apply the policy behind Clause 8 to a constitutional officer who works perhaps 300 days per year but not to an officer performing duties 120 days per year. I think not. Although the wording of Clause 8 may be somewhat quaint,

75. See Lyons Memorandum, supra note 16 (acknowledging that government's past practice of turning over gifts from foreign governments to those leaving government service was improper because "their acceptance without the consent of Congress is barred by the constitutional provision"); $c f$. Youngstown Sheet \& Tube Co. v. Sawyer, 343 U.S. 579, 613 (1952) (Frankfurter, J., concurring) (referring to Congress' "long-continued acquiescence" to executive branch action).

76. See, e.g., Foreign Gifts and Decorations Act, Pub. L. No. 89-673, 80 Stat. 952, § 4 (1966) ("Congress hereby gives its consent to a person to accept and retain a gift of minimal value").

77. See Dixon Memorandum, supra note 32 ("[I]t also seems reasonable to argue that Congress has consented, at least implicitly, to the membership of foreign nationals on the Council.").

78. Shanks Letter, supra note 45 (citing 5 U.S.C. $§ 7342(\mathrm{c})(1)(\mathrm{B})$ ).

79. Comp. of Emps. Detailed to Assist Foreign Gov'ts, 40 Op. Att'y Gen. 513 (1947).

80. See Memorandum from Leon Ulman, Deputy Assistant Att'y Gen., Office of Legal Counsel, to Peter Strauss, Gen. Counsel, Nuclear Regulatory Comm'n 6-7 (July 26, 1976), http://kathleenclark.law/wp-content/uploads/2019/07/1976-07-26-OLC-Ulman-NRC-GC-StraussFrench-govt-payment-to-Adv-Com-member-b-1.pdf [https://perma.cc/4KEQ-ZLS7] [hereinafter Ulman to Strauss Memorandum] (legislation creating the "Special Government Employee" category and exempting such employees from certain conflict of interest statutes did not constitute consent for those employees to accept benefits from foreign governments). 
the policy it bespeaks, requiring the undivided loyalty of individuals occupying positions of great public trust, has lost no force since it was adopted. ${ }^{81}$

In interpreting the clause, the Department has construed the phrase "Office of Profit or Trust" so that it reaches federal officials who can exercise governmental authority; has construed "present, Emolument, Office, or Title" to restrict a wide range of possible benefits; ${ }^{82}$ has construed "from any King, Prince, or foreign State" in a nuanced manner to reach situations where a foreign government decides to provide a benefit to a federal official; and has construed "Consent of the Congress" to ensure that Congress has affirmatively given its approval of any such arrangement with a foreign government. ${ }^{83}$

\section{TRUMP INTERPRETATION OF THE CLAUSE: PROTECT TRUMP, NOT THE REPUBLIC}

\section{A. Pre-Inauguration: Trump's Personal Lawyers Narrowly Construe Clause to Promote His Financial Interests}

After Donald Trump was elected but before he was inaugurated, his personal lawyers advanced a different interpretation of the Foreign Emoluments Clause - one that would allow Trump to receive payments from foreign governments through his businesses. The lawyers focused on two terms within the Clause, "present" and "Emolument," and argued for a narrow definition of each so that the Clause would not prohibit commercial payments from foreign governments to business entities owned by a federal official. ${ }^{84}$ In a January 11 , 2017 White Paper, Trump's lawyers took the position that the Clause had no application to business transactions in which "foreign governments pay fairmarket-value prices" because its term, "present," is limited to voluntary transfers of property without compensation, ${ }^{85}$ and "Emolument" should be limited to "a payment or other benefit received as a consequence of discharging the duties of an office. $"{ }^{86}$

Some commentators had argued that "Emolument" has the broader meaning reaching anything of value. ${ }^{87}$ In response, Trump's lawyers came up with five

81. Id. at 5 .

82. Emoluments Clause \& World Bank, 25 Op. O.L.C. 113, 114 (2001).

83. Lyons Memorandum, supra note 16.

84. See generally Morgan, Lewis \& Bockius LLP, Conflicts of Interest And the PRESIDENT (2017), https://assets.documentcloud.org/documents/3280261/MLB-White-Paper-1-10Pm.pdf [https://perma.cc/3AHQ-TS79].

85. Id. at 4 ("So long as foreign governments pay fair-market-value prices, their business is not a "present" because they are receiving fair value as a part of the exchange.")

86. Id.

87. See Norman L. Eisen \& Richard W. Painter, Trump Could be in Violation of the Constitution His First Day in Office, AtLantic (Dec. 7, 2016), https://www.theatlantic.com/ politics/archive/2016/12/trump-could-be-in-violation-of-the-constitution-his-first-day-in- 
arguments to justify their narrower definition. First, they argued that if "Emolument" were defined so broadly as to reach any kind of benefit, then the Clause's use of the term "present" would be redundant. ${ }^{88}$ While this argument helps explain why "Emolument" should not be construed so broadly as "any benefit," it does not explain why "Emolument" should be interpreted to exclude commercial transactions. Second, they pointed to a proposed 1810 Constitutional Amendment that used the term "Emolument," and contended that its meaning in that context would have excluded commercial transactions. ${ }^{89}$ Third, they invoked a passage in an 1850 Supreme Court decision, Hoyt v. United States, stating "the term emoluments . . . embrac[es] every species of compensation or pecuniary profit derived from a discharge of the duties of [an] office." ${ }^{.90}$ However, the Court used this definition in the context of a statute addressing the appropriate compensation for a particular office and was not providing a definition of the term outside of that specific statutory context.

Fourth, Trump's lawyers argued that "the factual circumstances giving rise to [non-judicial] opinions finding Foreign Emoluments Clause violations are different from those" involving Trump. ${ }^{91}$ It is true that the Department had never addressed the propriety of foreign government payments to a business owned by a President, but it had addressed a similar situation-foreign government payments to a business partially owned by a government official - and had prohibited that official from accepting profits derived from such payments. ${ }^{92}$ In its 1993 opinion, the Department ruled that a government official who was also a partner in a law firm could not accept money from the firm's work for foreign governments, even though he had not worked on those cases, because "the partnership would in effect be a conduit" for foreign governments. ${ }^{93}$ And finally, Trump's lawyers argued that a broader definition of the term would lead to "absurd results," such as prohibiting the President from receiving interest from federal or state bonds in a retirement account in light of the Constitution's Domestic Emoluments Clause. ${ }^{94}$

What is perhaps most important about the arguments marshaled by Trump's

office/509810/ [https://perma.cc/FZF2-DFQB] ("The Emoluments Clause prohibits the president from accepting anything of value from a foreign government." (emphasis in original)).

88. MORGAN, LEWIS \& BocKIUS LLP, supra note 84, at 5 ("it would have been redundant to list 'present' and "'Emolument' in the Clause separately, because any present would already qualify as a benefit").

89. Id. at 4-5.

90. Id. at 4 (quoting Hoyt v. United States, 51 U.S. 109, 135 (1850)).

91. Id.

92. See Applicability of the Emoluments Clause to Non-Gov't Members of ACUS, 17 Op. O.L.C. 114, 123 (1993).

93. Id.

94. MORGAN, LewIS \& BockiUs LLP, supra note 84, at 5. The term "emolument" is also used in the Domestic Emoluments Clause, which reads in full: "The President shall, at stated Times, receive for his Services, a Compensation, which shall neither be increased nor diminished during the Period for which he shall have been elected, and he shall not receive within that Period any other Emolument from the United States, or any of them.” U.S. CONST. art. II, § 1, cl. 7. 
personal lawyers is that they never grappled with the Clause's underlying purpose: To protect the government and the Republic from the kind of influence that could result from government officials accepting "any present, Emolument, Office, or Title, of any kind whatever" from foreign governments. ${ }^{95}$ The Department opinions interpreting the Clause repeatedly invoke not just its language, but also its purpose. A 1986 opinion written by now-Justice Samuel Alito, for example, asked whether the proposed $\$ 150$ payment from an Australian public university to a NASA scientist for reviewing a Ph.D. thesis "would raise the kind of concern (viz., the potential for 'corruption and foreign influence') that motivated the Framers in enacting the constitutional prohibition." 96 Trump's personal lawyers, on the other hand, limited themselves to technical (and ultimately unpersuasive) arguments that would strip the clause of its vigor and would empower foreign governments to potentially influence Trump by spending at his properties. Their interpretation would also enable all federal officials to accept unlimited sums from foreign governments, as long as the payments came through transactions with business entities. ${ }^{97}$

\section{B. Post-Inauguration: Department of Justice Adopts Trump's Narrow Interpretation}

Three days after Donald Trump was inaugurated as President, an anticorruption group filed a lawsuit against Trump claiming that his businesses' acceptance of money and other benefits from foreign governments violated the Constitution's Foreign Emoluments Clause. ${ }^{98}$ Five months later, the District of Columbia and Maryland filed a similar lawsuit against Trump, ${ }^{99}$ and two days

95. U.S. Const. art. I, $\S 9$, cl. 8.

96. Alito Memorandum, supra note 67, at 1; see also Applicability of the Emoluments Clause $\&$ the Foreign Gifts \& Decorations Act to the Göteborg Award for Sustainable Dev., 34 Op. O.L.C. 1, 2 (2010) (quoting same passage); Dixon Memorandum, supra note 32 (noting clause's anticorruption purpose and discounting risk of corruption arising when appointing individual who already "possesses a title or renders services to a foreign state"); Ulman. Memorandum to Gaine, supra note 41 (reviewing the facts regarding Harvard's arrangement with Indonesia "with the underlying purpose of the constitutional prohibition in mind," and finding Indonesia's payment of travel expenses "cannot be said to be "from" a foreign government within the meaning of" the clause).

97. One mitigating factor would be that nearly all executive branch officials — other than the President and Vice President - are bound by criminal and administrative restrictions on conflicts of limits. See, e.g., 18 U.S.C. § 208(a) (2019). Those statutes and regulations would limit the ability of a particular executive branch official to act on government matters affecting a foreign government from whom the official receives benefits.

98. Complaint at 1, Citizens for Responsibility \& Ethics in Wash. v. Trump, 276 F. Supp. 3d 174 (S.D.N.Y. 2017) (No. 1:17-cv-00458-RA). The lead plaintiff is also known by its acronym, CREW. The lawsuit also alleged violation of the constitution's Domestic Emoluments Clause. Id. at 22 .

99. See Complaint at 1, District of Columbia v. Trump, 291 F. Supp. 3d 725 (D. Md. 2018) 
after that, Senator Richard Blumenthal and 195 other members of Congress filed a third lawsuit with similar claims. ${ }^{100}$ In responding to those lawsuits, the Department changed its position on the meaning of the Clause and, following the lead of Donald Trump's private lawyers, adopted a narrow interpretation. ${ }^{101}$

The Trump Department of Justice invoked the same five arguments that Trump's private sector lawyers used in their January 2017 White Paper. ${ }^{102}$ It argued that interpreting "the term 'Emolument' to mean 'anything of value' would subsume the term 'present' in the Foreign Emoluments Clause and render it redundant." 103 The Department also argued that the never-ratified 1810 Constitutional Amendment supported its interpretation, ${ }^{104}$ and invoked the Supreme Court's narrow definition of the term in its 1850 Hoyt v. United States decision. ${ }^{105}$

The Department tweaked the Trump's lawyers' argument that prior OLC opinions could be distinguished on the basis of different facts. ${ }^{106}$ Instead of distinguishing those earlier opinions, the Department contends that its narrow definition is consistent with them, arguing that "in every published OLC . . . opinion" where a proposed emolument was prohibited, the facts "involved an employment relationship, or a relationship akin to an employment relationship,

(No. 17-cv-1596-PJM). This lawsuit also alleged violation of the constitution's Domestic Emoluments Clause. Id. at 24-30.

100. See Complaint at 18, Blumenthal v. Trump, 335 F. Supp. 3d 45 (D.D.C. 2018) (No. 1:17cv-1154-EGS). Two months later, five additional members of Congress joined the lawsuit, for a total of 201 plaintiffs. See Amended Complaint at 18-19, Blumenthal v. Trump, 335 F. Supp. 3d 45 (D.D.C. 2018) (No. 1:17-cv-1154-EGS).

101. See CREW v. Trump, Memorandum of Law, supra note 2; Statement of Points and Authorities in Support of Defendant's Motion to Dismiss, Blumenthal v Trump, 335 F. Supp. 3d 45 (D.D.C. 2018) (No. 17-cv-1154-EGS) [hereinafter Blumenthal v. Trump, Statement of Points and Authorities]; Memorandum in Support of Defendant's Motion to Dismiss, District of Columbia v. Trump, 291 F. Supp. 3d 725 (D. Md. 2018) (No. 17-cv-1596-PJM) [hereinafter D.C. v. Trump, Memorandum in Support of Trump].

102. See Morgan, Lewis \& Bockius LLP, supra note 84, at 5.

103. CREW v. Trump, Memorandum of Law, supra note 2, at 39; Blumenthal v. Trump, Statement of Points and Authorities, supra note 101, at 23; D.C. v. Trump, Memorandum in Support of Trump, supra note 101, at 36.

104. CREW v. Trump, Memorandum of Law, supra note 2, at 39 (stating "it is implausible that this amendment was intended or understood as providing for the revocation of the citizenship of anyone engaging in commerce with foreign governments"); Blumenthal v. Trump, Statement of Points and Authorities, supra note 101, at 22; D.C. v. Trump, Memorandum in Support of Trump, supra note 101 , at 30 .

105. CREW v. Trump, Memorandum of Law, supra note 2, at 27; Blumenthal v. Trump, Statement of Points and Authorities, supra note 101, at 17; D.C. v. Trump, Memorandum in Support of Trump, supra note 101, at 25.

106. See CREW v. Trump, Memorandum of Law, supra note 2, at 42; Blumenthal v. Trump, Statement of Points and Authorities, supra note 101, at 23; D.C. v. Trump, Memorandum in Support of Trump, supra note 101, at 34. 
with the foreign government." 107 But that assertion omits the Department's opinion prohibiting a federal official from accepting profits derived from foreign government payments to his law firm. ${ }^{108}$ In its Motion to Dismiss, the Department acknowledged the existence of that opinion in a footnote, ${ }^{109}$ but did not explain how it could be squared with its contention about "every published OLC . . . opinion." 110 In its Motions to Dismiss in the Blumenthal and D.C./MD lawsuits, the Department again relegated mention of that opinion to a footnote, but also asserted - without citing any language in the opinion - that its outcome was based on the fact that it involved a law firm rather than another type of business. ${ }^{111}$

Regarding the fifth argument - that a narrow definition was necessary to avoid absurd results - the Department doubled down on this by putting forward additional examples of the absurd results that it believed would follow if the Clause prohibited foreign government payments to Trump's commercial establishments. ${ }^{112}$ It is useful to examine this issue in some detail because the absurdity comes not from a broad definition of "emolument," but from the Department's failure to consider another component of the clause - whether the benefit should be deemed to come from a foreign government.

In the Emoluments Litigation cases, the Department contends that "royalties from foreign book sales received by a President . . . would offend the Foreign Emoluments Clause if any of them were attributable to purchase by a foreign government instrumentality, such as a foreign public university," citing the 1994 Department of Justice opinion on foreign universities hiring federal officials. ${ }^{113}$ Yet this argument is undermined by that very opinion, which indicates that a benefit provided by a foreign public university is not deemed to be "from" a foreign government if the university has functional independence from that

107. CREW v. Trump, Memorandum of Law, supra note 2, at 42 (referring also to published Comptroller General opinions); Blumenthal v. Trump, Statement of Points and Authorities, supra note 101, at 23; D.C. v. Trump, Memorandum in Support of Trump, supra note 101, at 34.

108. Applicability of the Emoluments Clause to Non-Gov't Members of ACUS, 17 Op. O.L.C. 119, 123 (1993).

109. CREW v. Trump, Memorandum of Law, supra note 2, at 43-44, n.62.

110. Id. at 42 .

111. Blumenthal v. Trump, Statement of Points and Authorities, supra note 101, at 36 n.47 (asserting that "[s]ituations involving law partners and their profit sharing are distinct from the financial interests at issue in this case," (citing the RESTATEMENT (THIRD) OF THE LAW GOVERNING LAWYers § 123 cmt. b (AM. LAW Inst. 2019); and MOdel Rules of Prof'L CONDUCT r. $1.10 \mathrm{cmt}$. (AM. BAR Ass'N 1983)); D.C. v. Trump, Memorandum in Support of Trump, supra note 101, at 49.

112. CREW v. Trump, Memorandum of Law, supra note 2, at 46 (contending that "a President could not hold United States Treasury bonds while in office"); Blumenthal v. Trump, Statement of Points and Authorities, supra note 101, at 25; D.C. v. Trump, Memorandum in Support of Trump, supra note 101 , at 33 .

113. CREW v. Trump, Memorandum of Law, supra note 2, at 46 (citing Applicability of Emoluments Clause to Emp. of Gov't Emp.'s by Foreign Pub. U., 18 Op. O.L.C. 13 (1994)); Blumenthal v. Trump, Statement of Points and Authorities, supra note 101, at 25; D.C. v. Trump, Memorandum in Support of Trump, supra note 101, at 33. 
government and its decisions are made without being influenced by that government. ${ }^{114}$ On the other hand, if a foreign government sought to enrich a U.S. President by directing its public universities to purchase his books, the Clause would prohibit the President from accepting such royalties. ${ }^{115}$ By examining this "absurd" result through the lens of the entire Clause and not just of the term "Emolument," it becomes clear that the broader definition of "Emolument" does not produce absurd results. Two district courts have ruled on the meaning of the Clause, and both rejected the Department's cramped interpretation. ${ }^{116}$ But an appellate court reversed one of those decisions on the basis of standing, ${ }^{117}$ and the Department has sought a writ of mandamus to reverse the other. ${ }^{118}$

\section{THE DEPARTMENT'S REVERSAL: FROM ROBUST TO RISIBLE PROTECTION}

For over 150 years, the Department used its opinion-writing function to provide robust protection against foreign government influence on federal officials. ${ }^{119}$ After President Trump was sued for violating the Foreign Emoluments Clause, the Department faced a critical juncture. ${ }^{120}$ Would it continue its longstanding policy and practice of protecting the Republic from foreign government influence, or would it abandon that position in order to protect the narrow private financial interests of President Trump? Former White House Counsel Robert Bauer called for President Trump to retain private counsel to represent him in the Emoluments Litigation, permitting career Department of Justice lawyers to develop a response independent of the presidential appointees leading the Department. ${ }^{121}$ Instead, President Trump's political appointees and career lawyers all signed the pleadings in which the Department has advocated for the narrow interpretation of the Foreign Emoluments Clause developed by Trump's private lawyers to protect his personal financial interests, defending his acceptance of unlimited payments from foreign governments through his

114. Applicability of Emoluments Clause to Emp't of Gov't Emps. by Foreign Pub. Univs., 18 Op. O.L.C. 13 (1994) (noting " $[\mathrm{t}]$ he Emoluments Clause of the Constitution does not apply in the cases of government employees offered faculty employment by a foreign public university where it can be shown that the university acts independently of the foreign state when making faculty employment decisions."')

115. See id.

116. District of Columbia and Maryland v. Trump, 315 F. Supp. 3d 875 (D. Md. 2018); Blumenthal v. Trump, 373 F. Supp. 3d 191 (D.D.C. 2019).

117. In re Trump, 2019 WL 2997909 (4th Cir. 2019).

118. Defendant's Notice of Petition for Writ of Mandamus, Blumenthal v. Trump, 373 F. Supp. 3d (D.D.C. 2019) (No. 1:17-cv-1154-EGS).

119. See infra app. 1.

120. Robert Bauer, Trump Has Been Sued. Here's Why the Justice Department Shouldn't Represent Him, WASH. PosT (May 4, 2017), https://www.washingtonpost.com/opinions/trump-hasbeen-sued-heres-why-the-justice-department-shouldnt-represent-him/2017/05/04/d4a316ea-304511e7-8674-437ddb6e813e_story.html?utm_term=.e64160b60401 [https://perma.cc/6WXQ-AQ7K].

121. Id. 
businesses. $^{122}$

While there are past examples of the Department changing its view on specific legal issues after a newly elected administration takes office, ${ }^{123}$ there is something unprecedented about this particular reversal. Past reversals have been based on changes in an administration's policy preferences and ideological commitments. ${ }^{124}$ This change, on the other hand, was based not on ideology, but on the personal financial interests of this particular President. Never before have the immense litigation resources of the Department been deployed to personally enrich a President. In essence, the Department of Justice has abandoned its institutional client, the United States, and is now litigating to advance the personal financial interests of Donald J. Trump.

122. See generally CREW v. Trump, Memorandum of Law, supra note 2; Blumenthal v. Trump, Statement of Points and Authorities, supra note 101; D.C. v. Trump, Memorandum in Support of Trump, supra note 101.

123. See Josh Blackman, Presidential Maladministration, 2018 U. ILL. L. REV. 397, 405-22 (2018) (cataloging examples of agencies reversing their earlier interpretations of statutes and describing the extent to which such reversals affect judicial deference to agencies).

124. See, e.g., Motor Vehicle Mfrs. Ass'n of U.S., Inc. v. State Farm Mut. Auto. Ins. Co., 463 U.S. 29, 59 (1983) (Rehnquist, J., concurring in part and dissenting in part) (noting that "[t]he agency's changed view of the standard [on seatbelts] seems to be related to the election of a new President of a different political party" and that "[a] change in administration brought about by the people casting their votes is a perfectly reasonable basis for an executive agency's reappraisal of the costs and benefits of its programs and regulations"); see also Blackman, supra note 123, at 420 (noting an "unapologetic embrace of presidential reversals"). 


\section{Appendix I \\ The Department of Justice Opinions Addressing the Foreign Emoluments Clause}

\begin{tabular}{|c|c|c|}
\hline Date & Title (or topic) & Cite (or web location) \\
\hline 1854-04-03 & Marshal of Florida & 6 Op. Att'y Gen. 409 (1854) \\
\hline $1871-11-23$ & Foreign Diplomatic Commission & 13 Op. Att'y Gen. 537 (1871) \\
\hline $1877-01-20$ & Offices of Trust & 15 Op. Att'y Gen. 187 (1877) \\
\hline 1902-09-08 & Gifts from Foreign Prince & 24 Op. Att’y Gen. 116 (1902) \\
\hline 1909-03-10 & $\begin{array}{l}\text { Delivery of an Insignia from the } \\
\text { German Emperor to a Clerk in } \\
\text { the Post-Office Department }\end{array}$ & 27 Op. Att’y Gen. 219 (1909) \\
\hline 1911-02-03 & $\begin{array}{c}\text { Field Assistant on the } \\
\text { Geological Survey-Acceptance } \\
\text { of an Order from the King of } \\
\text { Sweden }\end{array}$ & 28 Op. Att’y Gen. 598 (1911) \\
\hline 1947-04-17 & $\begin{array}{c}\text { Compensation of Employees } \\
\text { Detailed to Assist Foreign } \\
\text { Governments }\end{array}$ & 40 Op. Att'y Gen. 513 (1947) \\
\hline $1952-09-23$ & $\begin{array}{l}\text { The Constitutional Prohibition } \\
\text { Against Acceptance of Gifts from } \\
\text { Foreign Potentates }\end{array}$ & $\begin{array}{c}\text { www.justice.gov/olc/page/file/ } \\
935716 / \text { download }^{125}\end{array}$ \\
\hline 1953-11-13 & $\begin{array}{l}\text { Article I, Section 9, Clause } 8 \text { of } \\
\text { the Constitution-Its Meaning }\end{array}$ & {$\left[\right.$ not available] ${ }^{126}$} \\
\hline $1953-11-27$ & $\begin{array}{c}\text { Membership of Judge Parker on } \\
\text { the International Law } \\
\text { Commission }\end{array}$ & $\begin{array}{c}\text { www.justice.gov/olc/page/file/ } \\
935731 / \text { download }^{127}\end{array}$ \\
\hline 1954-10-04 & $\begin{array}{c}\text { Payment of Compensation to } \\
\text { Individual in Receipt of } \\
\text { Compensation from a Foreign } \\
\text { Government }\end{array}$ & $\begin{array}{c}\text { www.justice.gov/olc/page/file/ } \\
935721 / \text { download }^{128}\end{array}$ \\
\hline
\end{tabular}

125. Lyons Memorandum, supra note 16.

126. Memorandum from D.C. Stephenson, to Herzel H.E. Plaine, Article I, Section 9, Clause 8 of the Constitution -Its Meaning (Nov. 13, 1953) (cited in Emoluments Clause \& World Bank, 25 Op. O.L.C. 113, 115 (2001)).

127. Rankin Memorandum, supra note 44.

128. Rankin to Andretta Memorandum, supra note 49; cf. Assistant Comptroller General Weitzel to the Attorney General, 34 Comp. Gen. 331 (1955) (coming to opposite conclusion). 


\begin{tabular}{|c|c|c|}
\hline Date & Title (or topic) & Cite (or web location) \\
\hline $1957-10-15$ & $\begin{array}{l}\text { Appointments to Civil Rights } \\
\text { Commission }\end{array}$ & $\begin{array}{c}\text { www.justice.gov/olc/page/file/ } \\
935726 / \text { download }^{129}\end{array}$ \\
\hline $1958-02-18$ & $\begin{array}{l}\text { Historical survey re gifts from } \\
\text { foreign monarchs and } \\
\text { governments to Government } \\
\text { officers }\end{array}$ & $\begin{array}{l}\text { https://www.politico.com/f/?id } \\
=00000158-\mathrm{b} 544-\mathrm{d} 679-\mathrm{a} 75 \mathrm{f}- \\
\text { bff5f } 2 \mathrm{fe} 0001^{130}\end{array}$ \\
\hline $1961-11-03$ & $\begin{array}{c}\text { Employment of retired foreign } \\
\text { service officers by foreign } \\
\text { governments }\end{array}$ & {$[\text { not available }]^{131}$} \\
\hline $1962-10-16$ & $\begin{array}{l}\text { Invitation by Italian Government } \\
\text { to officials of the Immigration \& } \\
\text { Naturalization Service \& a } \\
\text { Member of the White House Staff }\end{array}$ & $\begin{array}{l}\text { www.justice.gov/olc/page/file/ } \\
935741 / \text { download }^{132}\end{array}$ \\
\hline $1963-05-10$ & $\begin{array}{c}\text { Proposal That the President } \\
\text { Accept Honorary Irish } \\
\text { Citizenship }\end{array}$ & 1 Op. O.L.C. Supp. 278 (1963) \\
\hline 1969-09-29 & $\begin{array}{c}\text { Indian government payments to } \\
\text { Atomic Energy Commission } \\
\text { employees }\end{array}$ & $\begin{array}{c}\text { https://www.politico.com/f/?id } \\
=00000158-\text { b52f-d012-ab5a- } \\
\text { b5af63ee0001 }{ }^{133}\end{array}$ \\
\hline 1974-04-26 & $\begin{array}{l}\text { Conditional gifts to the President } \\
\text { from anonymous donors }\end{array}$ & $\begin{array}{c}\text { https://www.politico.com/f/?id } \\
=00000158-\mathrm{b} 543-\mathrm{d} 012-\mathrm{ab} 5 \mathrm{a}- \\
\text { b5e399570001 }\end{array}$ \\
\hline $1974-05-10$ & $\begin{array}{c}\text { Appointment of a Foreign } \\
\text { National to the National } \\
\text { Voluntary Service Advisory } \\
\text { Council }\end{array}$ & $\begin{array}{l}\text { www.justice.gov/olc/page/file/ } \\
935961 / \text { download }^{135}\end{array}$ \\
\hline
\end{tabular}

129. Memorandum from W. Wilson White, Assistant Att'y Gen., Office of Legal Counsel, to the Att'y Gen., Appointments to Civil Rights Commission (Oct. 15, 1957).

130. Memorandum to Files, Historical Survey Re Gifts From Foreign Monarchs and Governments To Government Officers (Feb. 18, 1958).

131. Memorandum from Nicholas DeB. Katzenbach, Assistant Att'y Gen., Office of Legal Counsel, to Byron R. White, Deputy Att'y Gen. (Nov. 3, 1961) (cited in Applicability of 18 U.S.C. $\S 219$ to Retired Foreign Serv. Officers, 11 Op. O.L.C. 67, 68 n.4 (1987)).

132. Schlei Memorandum, supra note 41.

133. Rehnquist Letter, supra note 41.

134. Memorandum from Robert G. Dixon, Jr., Assistant Att'y Gen., Office of Legal Counsel, to Dudley H. Chapman, Associate Counsel to the President, Conditional Gifts to the President From Anonymous Donors (April 26, 1974).

135. Dixon Memorandum, supra note 32. 


\begin{tabular}{|c|c|c|}
\hline Date & Title (or topic) & Cite (or web location) \\
\hline 1974-08-07 & $\begin{array}{c}\text { Ability of Intermittent Consultant } \\
\text { to United States to Hold Similar } \\
\text { Position under Foreign } \\
\text { Government }\end{array}$ & $\begin{array}{l}\text { http://kathleenclark.law/wp- } \\
\text { content/uploads/2019/07/197 } \\
\text { 4-08-07-OLC-Lawton-DAG- } \\
\text { Silberman-re-Ability-of- } \\
\text { Intermittent-Consultant-to-US- } \\
\text { to-hold-similar-position- } \\
\text { under-a-for-govt-1.pdf }{ }^{136}\end{array}$ \\
\hline 1976-07-26 & Meaning of "Office" & $\begin{array}{l}\text { http://kathleenclark.law/wp- } \\
\text { content/uploads/2019/07/197 } \\
\text { 6-07-26-OLC-Ulman-NRC- } \\
\text { GC-Strauss-French-govt- } \\
\text { payment-to-Adv-Com- } \\
\text { member-b-1.pdf }{ }^{137}\end{array}$ \\
\hline 1976-11-15 & J. Edgar Hoover memorabilia & $\begin{array}{c}\text { https://www.politico.com/f/?id } \\
=00000158-\text { b5 545-d679-a75f- } \\
\text { bff564040000 }\end{array}$ \\
\hline 1977-04-11 & $\begin{array}{c}\text { Assumption by People's Republic } \\
\text { of China of Expenses of U.S. } \\
\text { Delegation }\end{array}$ & 2 Op. O.L.C. 345 (1977) \\
\hline 1978-02-08 & $\begin{array}{l}\text { Wedding gifts to President } \\
\text { Nixon's daughters }\end{array}$ & $\begin{array}{c}\text { www.justice.gov/olc/page/file/ } \\
936081 / \text { download }^{139}\end{array}$ \\
\hline 1980-08-11 & $\begin{array}{l}\text { Expense Reimbursement in } \\
\text { Connection with Chairman } \\
\text { Stone's Trip to Indonesia }\end{array}$ & $\begin{array}{c}\text { www.justice.gov/olc/page/file/ } \\
936091 / \text { download }^{140}\end{array}$ \\
\hline 1981-06-23 & $\begin{array}{l}\text { President Reagan's Ability to } \\
\text { Receive Retirement Benefits } \\
\text { from the State of California }\end{array}$ & 5 Op. O.L.C. 187 (1981) \\
\hline 1982-02-24 & $\begin{array}{c}\text { Application of the Emoluments } \\
\text { Clause of the Constitution and } \\
\text { the Foreign Gifts and } \\
\text { Decorations Act }\end{array}$ & 6 Op. O.L.C. 156 (1982) \\
\hline
\end{tabular}

136. Memorandum from Mary C. Lawton, Acting Assistant Att'y Gen., Office of Legal Counsel, to Laurence H. Silberman, Deputy Att'y Gen., Ability of Intermittent Consultant to United States to Hold Similar Position Under Foreign Government (Aug. 7, 1974), http://kathleenclark. law/wp-content/uploads/2019/07/1974-08-07-OLC-Lawton-DAG-Silberman-re-Ability-ofIntermittent-Consultant-to-US-to-hold-similar-position-under-a-for-govt-1.pdf [https://perma.cc/M8E7-6Y85].

137. Ulman to Strauss Memorandum, supra note 80.

138. Memorandum from Antonin Scalia, Assistant Att'y Gen., Office of Legal Counsel, to the Att'y Gen., J. Edgar Hoover Memorabilia (Nov. 15, 1976).

139. Letter from John M. Harmon, Assistant Att'y Gen., Office of Legal Counsel, to Allie B. Latimer, Gen. Counsel, Gen. Servs. Admin., (Feb. 8, 1978).

140. Ulman Memorandum to Gaine, supra note 41. 


\begin{tabular}{|c|c|c|}
\hline Date & Title (or topic) & Cite (or web location) \\
\hline 1983-03-17 & $\begin{array}{l}\text { Award from German Alexander } \\
\text { Von Humboldt Foundation }\end{array}$ & $\begin{array}{c}\text { www.justice.gov/olc/page/file/ } \\
936131 / \text { download }^{141}\end{array}$ \\
\hline $1986-05-23$ & $\begin{array}{l}\text { Emoluments Clause Questions } \\
\text { raised by NASA Scientist's } \\
\text { Proposed Consulting } \\
\text { Arrangement with the University } \\
\text { of New South Wales }\end{array}$ & $\begin{array}{c}\text { www.justice.gov/olc/page/file/ } \\
936146 / \text { download }^{142}\end{array}$ \\
\hline $1986-06-03$ & $\begin{array}{c}\text { Application of Emoluments } \\
\text { Clause to Part-Time Consultant } \\
\text { for the Nuclear Regulatory } \\
\text { Commission }\end{array}$ & 10 Op. O.L.C. 96 (1986) \\
\hline $1987-06-15$ & $\begin{array}{l}\text { Applicability of } 18 \text { USC \& } 219 \text { to } \\
\text { Retired Foreign Service Officers }\end{array}$ & 11 Op. O.L.C. 67 (1987) \\
\hline $1987-07-30$ & $\begin{array}{c}\text { Applicability of Emoluments } \\
\text { Clause to Proposed Service of } \\
\text { Government Employee on } \\
\text { Commission of International } \\
\text { Historians }\end{array}$ & 11 Op. O.L.C. 89 (1987) \\
\hline $1988-04-12$ & $\begin{array}{l}\text { Authority of Foreign Law } \\
\text { Enforcement Agents to Carry } \\
\text { Weapons in the United States }\end{array}$ & 12 Op. O.L.C. 67 (1988) \\
\hline $1988-08-29$ & $\begin{array}{l}\text { Application of the Emoluments } \\
\text { Clause to a Civilian Aide to the } \\
\text { Secretary of the Army }\end{array}$ & $\begin{array}{l}\text { https://www.justice.gov/olc/ } \\
\text { page/file/936181/download }\end{array}$ \\
\hline $1990-11-15$ & $\begin{array}{c}\text { Emoluments Clause and } \\
\text { Appointment to the President's } \\
\text { Committee on the Arts and } \\
\text { Humanities }\end{array}$ & [not available] $]^{144}$ \\
\hline 1991-04-29 & $\begin{array}{c}\text { Applicability of } 18 \text { U.S.C. } \$ 219 \\
\text { to Members of Federal Advisory } \\
\text { Committees }\end{array}$ & 15 Op. O.L.C. 65 (1991) \\
\hline
\end{tabular}

141. Shanks Letter, supra note 45.

142. Alito Memorandum, supra note 67.

143. Memorandum from John O. McGinnis, Deputy Assistant Att'y Gen., Office of Legal Counsel, to James H. Thessin, Assistant Legal Adviser for Mgmt., Dep't of State, Application of the Emoluments Clause to a Civilian Aide to the Secretary of the Army 3 (Aug. 29, 1988).

144. Armacost Memorandum, supra note 69. 


\begin{tabular}{|c|c|c|}
\hline Date & Title (or topic) & Cite (or web location) \\
\hline $1992-08-27$ & $\begin{array}{c}\text { Applicability of Emoluments } \\
\text { Clause to Employment of CFTC } \\
\text { Attorney by East China Institute } \\
\text { of Politics and Law }\end{array}$ & [not available] $]^{145}$ \\
\hline $1993-10-28$ & $\begin{array}{c}\text { Applicability of the Emoluments } \\
\text { Clause to Non-Government } \\
\text { Members of ACUS }\end{array}$ & 17 Op. O.L.C. 114 (1993) \\
\hline $1994-03-01$ & $\begin{array}{c}\text { Meaning of “Office of Profit or } \\
\text { Trust" }\end{array}$ & 58 ADMIN. L. REV. 36 \\
(2006)
\end{tabular}

145. Delahunty Memorandum, supra note 69.

146. Dellinger Letter, supra note 36.

147. Shiffrin Memorandum, supra note 29.

148. Koffsky Memorandum, supra note 72. 


\begin{tabular}{|c|c|c|}
\hline Date & Title (or topic) & Cite (or web location) \\
\hline 2005-03-09 & $\begin{array}{l}\text { Application of the Emoluments } \\
\text { Clause to a Member of the } \\
\text { President's Council on Bioethics }\end{array}$ & 29 Op. O.L.C. 55 (2005) \\
\hline 2007-04-16 & $\begin{array}{c}\text { Officers Of The United States } \\
\text { Within The Meaning Of The } \\
\text { Appointments Clause }\end{array}$ & 31 Op. O.L.C. 73 (2007) \\
\hline $2007-06-15$ & $\begin{array}{l}\text { Application of the Emoluments } \\
\text { Clause to a Member of the FBI } \\
\text { Director's Advisory Board }\end{array}$ & 31 Op. O.L.C. 154 (2007) \\
\hline $2009-05-20$ & $\begin{array}{c}\text { Validity Of Statutory Rollbacks } \\
\text { As A Means Of Complying With } \\
\text { The Ineligibility Clause }\end{array}$ & 33 Op. O.L.C. _ $(2009)^{149}$ \\
\hline 2009-12-07 & $\begin{array}{l}\text { Applicability of the Emoluments } \\
\text { Clause and the Foreign Gifts } \\
\text { and Decorations Act to the } \\
\text { President's Receipt of the Nobel } \\
\text { Peace Prize }\end{array}$ & 33 Op. O.L.C. _ (2009) \\
\hline $2010-06-03$ & $\begin{array}{c}\text { Applicability of the Emoluments } \\
\text { Clause to Nongovernmental } \\
\text { Members of ACUS }\end{array}$ & 34 Op. O.L.C. _ $(2010)^{151}$ \\
\hline $2010-10-06$ & $\begin{array}{c}\text { Applicability of the Emoluments } \\
\text { Clause \& the Foreign Gifts \& } \\
\text { Decorations Act to the Göteborg } \\
\text { Award for Sustainable } \\
\text { Development }\end{array}$ & 34 Op. O.L.C. _ $(2010)^{152}$ \\
\hline
\end{tabular}

149. Available at www.justice.gov/sites/default/files/olc/opinions/2009/05/31/ineligibilityclause_0.pdf.

150. Available at www.justice.gov/file/18441/download.

151. Available at www.justice.gov/file/18411/download.

152. Available at www.justice.gov/file/18401/download. 


\section{Appendix II}

\section{Comptroller General Opinions on the Foreign Emoluments Clause}

\begin{tabular}{|c|c|c|}
\hline Date & Holding & Cite \\
\hline $1955-01-12$ & $\begin{array}{l}\text { Justice Department employee may } \\
\text { accept annuity payments from Germany } \\
\text { as reparations for wrongful acts } \\
\text { inflicted by Nazi regime }\end{array}$ & 34 Comp. Gen. $331^{153}$ \\
\hline $1957-08-26$ & $\begin{array}{l}\text { Newly appointed court crier may not } \\
\text { accept United Kingdom military } \\
\text { pension }\end{array}$ & 37 Comp. Gen. 138 \\
\hline 1962-05-01 & $\begin{array}{l}\text { Congress consented to retired military } \\
\text { reserve officers being employed by } \\
\text { foreign governments }\end{array}$ & 41 Comp. Gen. 715 \\
\hline $1963-12-12$ & $\begin{array}{l}\text { Factors to consider re: retired naval } \\
\text { officer could be employed by foreign } \\
\text { public university }\end{array}$ & $\begin{array}{l}\text { B- } 152844 \text { (Comp. } \\
\text { Gen.), } 1963 \text { WL } 3509\end{array}$ \\
\hline 1964-08-31 & $\begin{array}{l}\text { Civil Service Commission employee } \\
\text { does not hold an "office" in the } \\
\text { constitutional sense }\end{array}$ & $\begin{array}{l}\text { B- } 154223 \text { (Comp. } \\
\text { Gen.), } 1964 \text { WL } 2394\end{array}$ \\
\hline 1964-09-11 & $\begin{array}{l}\text { Retired coast guard member's receipt } \\
\text { of salary from Department of Education } \\
\text { in Tasmania violated clause; his } \\
\text { retirement pay will be docked the } \\
\text { amount of that salary }\end{array}$ & 44 Comp. Gen. 130 \\
\hline $1964-10-23$ & $\begin{array}{l}\text { Retired enlisted coast guard member } \\
\text { holds an "office" within meaning of } \\
\text { clause }\end{array}$ & 44 Comp. Gen. 227 \\
\hline 1964-11-10 & $\begin{array}{l}\text { Domestic Emoluments Clause prohibits } \\
\text { President Kennedy from accepting } \\
\text { military retirement pay while President }\end{array}$ & B- $153438^{154}$ \\
\hline $1964-12-28$ & $\begin{array}{l}\text { Retired coast guard member violated } \\
\text { foreign emoluments clause by } \\
\text { accepting salary from Tasmania } \\
\text { Department of Education }\end{array}$ & $\begin{array}{l}\text { B- } 154213 \text { (Comp. } \\
\text { Gen.), } 1964 \text { WL } 1865\end{array}$ \\
\hline $1966-02-03$ & $\begin{array}{l}\text { Retired military officer may not accept } \\
\text { retirement pay while employed by } \\
\text { foreign government }\end{array}$ & B- $158396^{155}$ \\
\hline
\end{tabular}

153. Contra Rankin to Andretta Memorandum, supra note 49.

154. Cited in B- 207467 (Comp. Gen.), 1983 WL 27823.

155. Cited in 53 Comp. Gen. 753 (1974). 


\begin{tabular}{|c|c|c|}
\hline Date & Holding & Cite \\
\hline 1970-06-01 & $\begin{array}{l}\text { Military officer may not accept } \\
\text { monetary reward from Colombia for } \\
\text { supplying information about } \\
\text { contraband }\end{array}$ & 49 Comp. Gen. 819 \\
\hline 1972-06-01 & $\begin{array}{l}\text { Retired Public Health Service officer } \\
\text { holds an "office" within meaning of } \\
\text { clause; can't accept retirement pay } \\
\text { while employed by Canadian } \\
\text { government }\end{array}$ & 51 Comp. Gen. 780 \\
\hline 1974-04-09 & $\begin{array}{l}\text { Retired military officer can't accept } \\
\text { retirement pay while working for } \\
\text { corporation owned by Israel }\end{array}$ & 53 Comp. Gen. 753 \\
\hline $1976-08-24$ & $\begin{array}{l}\text { Whether a retired foreign service } \\
\text { officer is an "officer" }\end{array}$ & B- $126318^{156}$ \\
\hline $1977-10-13$ & $\begin{array}{l}\text { Retirement pay for retired military } \\
\text { member employed by foreign } \\
\text { government will be withheld in amount } \\
\text { equal to amount received from foreign } \\
\text { government because "the emoluments } \\
\text { are accepted on behalf of the United } \\
\text { States" }\end{array}$ & $\begin{array}{l}\text { B- } 178538 \text { (Comp. } \\
\text { Gen.), } 1977 \text { WL } \\
12064\end{array}$ \\
\hline 1978-04-07 & $\begin{array}{l}\text { Congress' enactment of legislation } \\
\text { consenting to retired officers' } \\
\text { employment by foreign government } \\
\text { was not retroactive }\end{array}$ & $\begin{array}{l}\text { B- } 175166 \text { (Comp. } \\
\text { Gen.), } 1978 \text { WL } \\
10026\end{array}$ \\
\hline $1979-05-03$ & $\begin{array}{l}\text { Forms of compensation other than } \\
\text { salary are also prohibited, such as free } \\
\text { or reduced transportation, household } \\
\text { goods shipments at employer expense, } \\
\text { housing allowances }\end{array}$ & 58 Comp. Gen. 487 \\
\hline
\end{tabular}

156. Discussed in B- 199061 (Comp. Gen.), 1980 WL 16442. 


\begin{tabular}{|c|c|c|}
\hline Date & $\begin{array}{l}\text { Holding } \\
\end{array}$ & Cite \\
\hline $1979-05-25$ & $\begin{array}{l}\text { Retired military members who accept } \\
\text { emoluments incident to employment by } \\
\text { foreign governments "are deemed [to } \\
\text { have] accepted [those emoluments] on } \\
\text { behalf of the United States, and } \\
\text { therefore, the members' retired pay is } \\
\text { to be withheld in an amount equal to } \\
\text { such emoluments" }\end{array}$ & 58 Comp. Gen. 566 \\
\hline 1979-12-04 & $\begin{array}{c}\text { Construed Foreign Relations } \\
\text { Authorization Act, Fiscal Year 1978, } \\
\text { Public Law 95-105, August 17, 1977, } \\
\text { 91 Stat. 844, 859-860 as congressional } \\
\text { consent for retired military members } \\
\text { employed by foreign governments at } \\
\text { time of enactment to start receiving } \\
\text { retirement pay as soon as they obtained } \\
\text { secretarial approval for foreign } \\
\text { government employment, even if the } \\
\text { prior deductions had not completely } \\
\text { offset the emoluments they received } \\
\text { from foreign governments }\end{array}$ & $\begin{array}{c}\text { B- } 193562 \text { (Comp. } \\
\text { Gen.), } 1979 \mathrm{WL} \\
11736^{157}\end{array}$ \\
\hline 1980-06-13 & $\begin{array}{l}\text { State department takes the position that } \\
\text { retired foreign service officers and } \\
\text { retired foreign service information } \\
\text { officers continue to be officers for } \\
\text { purpose of clause }\end{array}$ & $\begin{array}{c}\text { B- } 199061 \text { (Comp. } \\
\text { Gen.), } 1980 \mathrm{WL} \\
16442\end{array}$ \\
\hline 1980-07-17 & $\begin{array}{l}\text { Standard for recouping retirement pay } \\
\text { when retired military officer has } \\
\text { received approval from one but not } \\
\text { both cabinet secretaries }\end{array}$ & $\begin{array}{c}\text { B- } 198557 \text { (Comp. } \\
\text { Gen.), } 1980 \mathrm{WL} \\
16290\end{array}$ \\
\hline 1982-03-25 & $\begin{array}{l}\text { Standard for recouping retirement pay } \\
\text { received during period of unauthorized } \\
\text { employment by foreign government }\end{array}$ & 61 Comp. Gen. 306 \\
\hline 1983-01-18 & $\begin{array}{l}\text { President Reagan's acceptance of a } \\
\text { retirement allowance from the State of } \\
\text { California does not violate Domestic } \\
\text { Emoluments Clause }\end{array}$ & $\begin{array}{c}\text { B- } 207467 \text { (Comp. } \\
\text { Gen.), } 1983 \mathrm{WL} \\
27823\end{array}$ \\
\hline
\end{tabular}

157. Overruled by 61 Comp. Gen. 306. 


\begin{tabular}{|c|c|c|}
\hline Date & Holding & Cite \\
\hline 1983-06-02 & $\begin{array}{l}\text { Clause does not apply if retired military } \\
\text { officer from being employed by } \\
\text { "American Motors Corporation, which } \\
\text { is } 46.9 \% \text { owned by Renault, which is } \\
92 \% \text { owned by the French } \\
\text { government," but would apply "where } \\
\text { it appears that a domestic corporation is } \\
\text { ultimately controlled by a foreign } \\
\text { government and the domestic } \\
\text { corporation acts as an agent or } \\
\text { instrumentality of a foreign } \\
\text { government" }\end{array}$ & 62 Comp. Gen. 432 \\
\hline $1983-10-17$ & $\begin{array}{l}\text { Saudi Arabian Airlines, which is } \\
\text { attached to Saudi Ministry of Defense } \\
\text { and Aviation, managed by board } \\
\text { headed by Minister of Defense and } \\
\text { Aviation or his nominee, with other } \\
\text { board members appointed by Council } \\
\text { of Ministers on nomination by the } \\
\text { Minister of Defense and Aviation, is an } \\
\text { instrumentality of the Saudi Arabian } \\
\text { government }\end{array}$ & $\begin{array}{c}\text { B- } 212724 \text { (Comp. } \\
\text { Gen.), } 1983 \text { WL } \\
27899\end{array}$ \\
\hline $1985-03-11$ & $\begin{array}{l}\text { Retired military officers who were } \\
\text { attorneys employed by or "of counsel" } \\
\text { at a law firm could not serve as legal } \\
\text { counsel for the Office of the Saudi } \\
\text { Military Attache without congressional } \\
\text { consent even though no attorney will be } \\
\text { entitled to or receive any compensation } \\
\text { on the basis of collection by the firm } \\
\text { from any particular client or for any } \\
\text { particular service, noting that the Saudi } \\
\text { Government would pay the professional } \\
\text { corporation for the services performed } \\
\text { and retired military "officers and they } \\
\text { in turn would benefit from these } \\
\text { payments through the receipt of salary } \\
\text { and other compensation and benefits } \\
\text { from the professional corporation" }\end{array}$ & $\begin{array}{c}\text { B- } 217096 \text { (Comp. } \\
\text { Gen.), } 1985 \text { WL } \\
52377\end{array}$ \\
\hline
\end{tabular}




\begin{tabular}{|c|c|c|}
\hline Date & Holding & Cite \\
\hline 1986-03-10 & $\begin{array}{l}\text { Retired military officer "effectively was } \\
\text { an employee of the Saudi Arabian } \\
\text { Government since it could control and } \\
\text { direct him" even though he formally } \\
\text { worked for Delaware company; the } \\
\text { clause "requires the broadest possible } \\
\text { scope and application, and have held } \\
\text { that the transportation and payment of } \\
\text { other expenses" }\end{array}$ & 65 Comp. Gen. 382 \\
\hline 1989-06-21 & $\begin{array}{l}\text { Retired military officer was employed } \\
\text { by ARAMCO at time when it was } \\
\text { unclear whether Saudi Arabia owned } \\
\text { company; government waived any } \\
\text { claim against officer's estate }\end{array}$ & $\begin{array}{c}\text { B- } 231498 \text { (Comp. } \\
\text { Gen.), } 1989 \mathrm{WL} \\
240844\end{array}$ \\
\hline 1990-01-19 & $\begin{array}{l}\text { Applies 5-part test to determine } \\
\text { whether retired military officer is } \\
\text { employed by foreign government; "for } \\
\text { purposes of the constitutional } \\
\text { prohibition, [retired military officer] } \\
\text { was an employee of the Saudi Arabian } \\
\text { government which had the power to fire } \\
\text { him and, equally important, to control } \\
\text { his conduct by supervising and } \\
\text { directing his activities" "Our consistent } \\
\text { position has been to give this } \\
\text { constitutional provision the broadest } \\
\text { possible scope and application." }\end{array}$ & 69 Comp. Gen. 175 \\
\hline 1993-10-12 & $\begin{array}{l}\text { "The term 'foreign State' should be } \\
\text { interpreted to include local } \\
\text { governmental units within a foreign } \\
\text { country as well as the national } \\
\text { government itself." "The intent of the } \\
\text { constitutional prohibition is to curb } \\
\text { foreign influence upon government } \\
\text { officials. Foreign governmental } \\
\text { influence can just as readily occur } \\
\text { whether a member is employed by local } \\
\text { government within a foreign country or } \\
\text { by the national government of the } \\
\text { country." }\end{array}$ & $\begin{array}{c}\text { B- } 251084 \text { (Comp. } \\
\text { Gen.), } 1993 \mathrm{WL} \\
426335\end{array}$ \\
\hline
\end{tabular}




\section{Appendix III}

Other Federal Government Opinions on the Foreign Emoluments Clause

U.S. Department of Justice, Immigration and Naturalization Service General Counsel Op. No. 96-9, Questions Pertaining to the United States/Canada Accord on Inspections Operations at Our Shared Border (June 26, 1996)

"A person exercising law enforcement powers on behalf of the United States holds an office of trust under the Emoluments Clause. Because Canadian officers are paid a salary by Canada, they accept an emolument from a foreign government. Therefore, they may not exercise United States law enforcement powers, including immigration inspections, without the consent of Congress."

\section{U.S. Department of Defense, Standards of Conduct Office, White Paper: Application} of the Emoluments Clause to DoD Civilian Employees and Military Personnel ${ }^{158}$

White paper addressing definition of "emolument," including the types of employment that may involve an "emolument;" the federal officials who hold an "Office of Profit or Trust;" what counts as a "foreign state;" and details regarding Congressional consent for retired military personnel to accept foreign government salaries, including specific procedures for obtaining advance approval from the Departments of Defense and State.

U.S. House of Representatives, Office of Congressional Ethics, Report: Review No. 17-1147 (June 2, 2017)

"the term 'emoluments' is not limited to payments from a foreign government that result from an individual's official duties;" "the receipt of profit from a foreign government for rental property may implicate the constitutional prohibition against receipt of 'any emolument' of 'any kind whatever' from a foreign state."

158. The White Paper is not dated, but appears to have been issued in late 2012. (Footnotes 34 and 37 therein refer to websites "last viewed on September 10, 2012.") 